\title{
A transversal methodology for the implementation of virtual reality in Architecture learning
}

\author{
Carlos Rosa-Jiménez, Ferrán Ventura-Blanch
}

Department of Arts and Architecture, Universidad de Málaga, Spain.

\begin{abstract}
Virtual reality (VR) has achieved an adequate level of development in education and research in higher education The training in Architecture requires a reflection on the incorporation of new design technologies at the Degree and Master's level, due, in part, to the dissatisfaction of the students with the poor implementation of these technologies. The pedagogical possibilities of VR are very high. The aim of this paper is to propose a transversal methodology for several subjects in the same semester. It consists of the virtual recreation of a work of relevant architecture in the history of contemporary Architecture. The possibilities of implementing VR in the architectonic subjects are analyzed. This methodology takes advantage of the potential of this technology to create a transversal educational activity, for different subjects and areas of knowledge in the same academic year. Subsequently, the different phases for its implementation are described in terms of activities and scenarios. The paper concludes that transversal methodology offers the opportunity to analyze the same building from different disciplines, checking the interrelation between them, and saves time for the student in completing teaching assignments.
\end{abstract}

Keywords: Virtual Reality; architecture; transversal learnin; educational technology. 


\section{Introduction}

The pedagogical use of the virtual reality (VR) can be a great motivation for the student. Vera Ocete (2003) stresses that the learning curve with VR is faster, and greater and better content assimilation can be achieved with VR than with traditional teaching tools, mainly because students use almost all of their senses in the VR learning experience. Thus, in 2015 UNESCO recognized the work of the Institute of Technical Education of Singapore in the development of a virtual and augmented reality program, capable not only of enhancing practical learning, but also of improving the assimilation and evaluation of skills.

The use of VR for the representation of three-dimensional space and architectural projects has been used in Architecture teaching with 3D-models of buildings or architectural elements (Navarro Delgado \& Fonseca Escudero, 2017). However, these are activities that are carried out in a single subject. Therefore, this paper tries to present a methodology that takes advantage of the potential of this technology to create a transversal educational activity, for different subjects and areas of knowledge in the same academic year.

\section{Background}

VR is defined as a "highly interactive, computer-generated environment. It can be graphics-based or text-based. Some types of VR, such as a collaborative virtual environment (CVE), combine graphics and text" (Pantelidis \& Vinciguerra, 2010:151). Many authors have analyzed the applications of VR in higher education. Bowman, Hodges, Allison, \& Wineman (1999:170) described its application in social studies as follows: "Villages, town, and city areas, home interiors, habitats, and maps are constructed to provide a feeling of being there". Abulrub, Attridge, \& Williams (2011) discussed the benefits of using a 3D photorealistic interactive and immersive virtual environment for engineering undergraduates and postgraduate teaching, learning and training. Häkkilä, Colley, Väyrynen, \& Yliharju (2018) highlighted the implementation of VR in smart buildings, Lisichenko (2015) in Geography education, and Navarro Delgado \& Fonseca Escudero (2017) in urban design. There is a great potential for future applications of VR in Architecture and Urbanism because both of them involve visual simulation, spatial thinking, and learning-by-doing activities (Passig \& Sharbat, 2000:176). The use of VR in these subjects is a natural evolution of computer-assisted instruction (CAI) or computerbased training (CBT) (Pantelidis \& Vinciguerra, 2010:161). There are two VR modes: desktop and immersive. Desktop VR is popular in CVEs used in education and training where participants interacts with others via avatars (e.g., the 2D virtual world of Whyville or the River City Project). Immersive VR has important benefits in Architecture and Urbanism (see Table 1): it reduces the cognitive effort required for interpretation, enables the creation of a dynamic interaction and introduces a novel persepective (Wickens, 1992). 
Table 1. Some benefits and values of VR in the Architecture learning process.

\begin{tabular}{cc}
\hline VR values & Author \\
\hline Motivation & Wickens (1992), Winn (1993) \\
Different perspective & Wickens (1992) \\
Immersion, interaction and promoting to \\
learn from non-symbolic first-person \\
experience \\
Stimulate learning and comprehension
\end{tabular}

\section{Methodology}

We applied the Constructivist Learning Environments (CLE) model (Jonassen, 2000), through the Project-Based Learning (PBL) technique where the common project consists of the virtual recreation of a work of relevant architecture in the history of contemporary Architecture. We use three scenarios: classroom (C), laboratory (L) and virtual learning environment (VLE). All the subjects involved shared the following aspects:

- Coordination of teachers: the coordinators of the subjects involved met at the beginning, middle and end of the course.

- Work groups: the students were organized in teaching units of 25 students and in work groups of 5 .

- The Virtual Moodle Platform of the Virtual Campus provided teaching resources and was used for evaluating and social interaction.

- Collaborative evaluation.

To establish the transversality of the subject, it is necessary to previously determine (a) which subjects can use 3D simulations and (b) if they allow the development of a shared work. In Architecture, VR can be used in many of subjects since, traditionally, students have worked with models and rendered images so the immersive visualization seems an immediate step. Pantelidis (1997) justifies the incorporation of the model when the realization of an attractive class requires travel, money and/or logistics, and shared experiences are desired in a group. Adapting the methodology of Pantelidis (1997), we classified subjects as transversal if they met the following objectives:

General Objectives (subject) $\rightarrow$ Related to 3D simulations (subject) $\rightarrow$ Related to 3D simulations of a building and its environment (transversal). 
From the expected cross-sectional results, the following were determined: (a) level of realism of the building, (b) type of interaction, (c) type of sensory input and output required, (d) RV software. Finally, we designed and built the virtual environment.

\section{Results}

\subsection{Teaching transversality}

The first course in Architecture (first semester) was used as an example of transversal model of VR implementation. Representing a building in immersive VR enables the objectives of the three selected subjects to be achieved (Table 2).

Table 2. Transversal contributions of knowledge areas.

\begin{tabular}{|c|c|c|}
\hline Id & Subject & Transversal objective \\
\hline WSI & Workshop IA & $\begin{array}{l}\text { Master drawing techniques, including digital techniques } \\
\text { applied to architecture and urban planning }\end{array}$ \\
\hline IAC & $\begin{array}{l}\text { Introduction to } \\
\text { architectonic } \\
\text { construction }\end{array}$ & $\begin{array}{l}\text { Ability to graphically describe how construction systems are } \\
\text { organized and solve practical cases on the application of } \\
\text { organization materials for structures, facades, roofs, interior } \\
\text { elements and installations of buildings of small complexity. } \\
\text { How it works, how it is built, what they are called. }\end{array}$ \\
\hline IAH & $\begin{array}{l}\text { Introduction to } \\
\text { architectonic } \\
\text { history }\end{array}$ & $\begin{array}{l}\text { Analysis of an example of modern architecture to be placed in } \\
\text { its historical context. }\end{array}$ \\
\hline
\end{tabular}

The goal was the development of 15 representative houses of contemporary architecture in VR. Given the time constraints, the dwellings must be simple in the use of geometric shapes (e.g. La ville Savoye by Le Corbusier). The level of realism must differentiate the construction materials and the environmental conditions (day and night). The sensory output is through HMD (head-mounted display) of the HTC Vive type (https://www.vive.com/us/). In the generation of 3D modeling (CAD technologies) free internet programs and educational licenses for students are used. Free tools like Google Blocks ${ }^{\mathrm{TM}}$ (https://arvr.google.com/blocks/), Paint Lab $\mathrm{VR}^{\mathrm{TM}}$ allow the drawing and sculpting of 3D models (http://paintlabvr.com/). The modeling used were the Rhinoceros ${ }^{\mathrm{TM}}$ $3 \mathrm{D}$ and Autodesk ${ }^{\mathrm{TM}}$ educational edition. 


\subsection{Design and construction of the virtual environment}

The methodological development follows the scheme in Table 3, which describes the sequence of phases, activities and learning scenarios.

Table 3. Methodological development for the subjects involved, in relation to the activities and learning scenarios (LS).

\begin{tabular}{clc}
\hline \multicolumn{1}{c}{ Phase } & \multicolumn{1}{c}{ Activity } & LS \\
\hline $\begin{array}{c}\text { 0. Seminar } \\
\text { 1. Research on the } \\
\text { building }\end{array}$ & $\begin{array}{c}\text { Formation of the content creation team (teaching staff and } \\
\text { students) and election of building }\end{array}$ & C/VLE \\
& IAC: material and construction system data & C \\
& WSI: theoretical bases on the computer program & C/VLE \\
2. Modeling & 3D modeling of design and construction elements & C \\
3. Immersion in VR & $\begin{array}{l}\text { Importing rendering to visualization program, adding } \\
\text { materials and lighting }\end{array}$ & L \\
4. Evaluation & Immersion and assessment by students & L \\
5. Presentation & Presentation of results in each subject & C \\
\hline
\end{tabular}

For each of the phases, the activities to be carried out were developed as follows:

0. Seminar. The 75 students were organized into 15 groups of 5 students. In the seminar a presentation of the work was made and the houses were distributed among the groups.

1. Research on the building. Students researched on the architectural work selected for the $3 \mathrm{D}$ survey. The proposed software was required include to immersive VR. In addition, the VLE provided conceptual information on 3D modeling techniques, associated technology, and usability standards.

2. Modeling. Modeling was carried out using the Autocad 3D educational version program. The 3D model contains the data necessary to visualize or render a three-dimensional object, and can contain two types of information (Moreno, Aguilar, \& Hidrobo, 2018): (a) the geometry and construction systems, and (b) the attributes of the surface in terms of color, texture and lighting that confer realism to the representation.

3. The VR immersion was carried out in the Fab-Lab laboratory, where the HMD is located. Using a second software, the 3D model was opened to prepare the VR environment (lighting, textures, animations, effects, etc.), and it was connected to the HMD sending the 
information for immersive viewing. Autodesk Live - that enables interactive viewing for Revit (BIM model viewing) - , Autodesk VRED Professional, and Rhinoceros ${ }^{\mathrm{TM}}$ were used. The laboratory has a computer that uses a GTX 970 video card to use Professional VRED with HTC Vive.

4. Evaluator experience. This was carried out in two phases:

- In the first part, a meeting was held. The students in a group distributed among themselves the virtual vision of 3 buildings of the other groups. Wickens (1992) suggests the concept of visual momentum to address the issues of cognitive loss. Students have to assess: (a) use of consistent representations, (b) use of graceful transititons.

- Evaluation through a test. The evaluation was conducted through test surveys and BLA (Bipolar Laddering) questionnaires (Pifarré \& Tomico, 2007). Navarro Delgado \& Fonseca Escudero (2017) proposed the use of tests (from 0 to 5) to evaluate the implementation of these technologies as well as for selecting the sample model and the type of analysis.

5. Specific presentations for each transversal subject (IAH, IAC, WSI) using the 3D model: (a) in IAH, the students can use images of VR to explain the story of the building; (b) in IAC, the students can use 3D model images in the descriptions of its constructive elements. Even the VR architectonic model can be used later by other subjects (e.g. Architectonic Projects).

\section{Discussion and conclusion}

Although in general, game-based learning environments are more effective than virtual worlds or simulations (Merchant, Goetz, Cifuentes, Keeney-Kennicutt, \& Davis, 2014), in the case of Architecture, the development of buildings in VR becomes complete when the sensitive dimension is incorporated into the 2D and 3D dimensions of work. According to Bowman, Hodges, Allison, \& Wineman (1999:169): "The experience of creating a simulated environment or model is important to the learning objective", especially in the following advantages of the model.

Transversal methodology enhances the student's research role and it offers students the chance to become real scientists (Dede, Ketelhut, \& Ruess, 2003). It offers the opportunity to analyze the same building from different disciplines, checking the interrelation between them, and saves time for the student in completing teaching assignments.

It fosters the constructivist dimension of knowledge, by actually building a model in which sensations produced by the Architecture can be experienced and analyzed. VR allows the incorporation of the sensitive dimension of the Architecture, an aspect that currently can only be visualized by means of $2 \mathrm{D}$ rendered images. The methodology allows students to 
relate the sensation in the perception of Architecture with all the related subjects in the construction of the VR model.

On the other hand, this model allows to build an open repository of buildings that can be used in other subjects. In this way, the elements built virtually can be used for all the subjects in the curriculum.

Among the drawbacks, it should be noted that the proposal involves an important coordination effort between tutors in different subjects and areas of knowledge. In terms of the software and hardware necessary for the application of the method, the existence of virtual reality laboratories clearly facilitates its implementation, so this method can be difficult in schools that lack it. It is desirable that each student has an HMD, which allows the work to be done to be divided. In this sense, the implementation of cardboards that turn smartphones into VR devices solves this problem. For this reason, the rapid advances in technology clearly support the implementation of VR as an essential tool in advanced Architectural teaching.

\section{References}

Abulrub, A. G., Attridge, A., \& Williams, M. A. (2011). Virtual reality in engineering education: The future of creative learning. International Journal of Emerging Technologies in Learning, 6(4), 4-11. https://doi.org/10.3991/ijet.v6i4.1766

Bowman, D. A., Hodges, L. F., Allison, D., \& Wineman, J. (1999). The educational value of an information-rich virtual environment. Presence: Teleoperators and Virtual Environments, 8(3), 317-331. https://doi.org/10.1162/105474699566251

Dede, C., Ketelhut, D., \& Ruess, K. (2003). Designing for Motivation and Usability in a Museum-based Multi-User Virtual Environment. In Paper presented at the American Educational Research Association Conference.

Häkkilä, J., Colley, A., Väyrynen, J., \& Yliharju, A.-J. (2018). Introducing Virtual Reality Technologies to Design Education. International Journal of Media, Technology and Lifelong Learning Seminar.Net, 14(1), 1-12.

Jonassen, D. H. (2000). El diseño de entornos constructivistas de aprendizaje. In G. E. Snelbecker (Ed.), Diseño de la instrucción: teorías y modelos (pp. 225-250). Madrid: Aula XXI Santillana.

Lisichenko, R. (2015). Issues Surrounding the Use of Virtual Reality in Geographic Education. Geography Teacher, 12(4), 159-166. https://doi.org/10.1080/19338341.2015.1133441

Merchant, Z., Goetz, E. T., Cifuentes, L., Keeney-Kennicutt, W., \& Davis, T. J. (2014). Effectiveness of virtual reality-based instruction on students' learning outcomes in K-12 and higher education: A meta-analysis. Computers and Education, 70, 29-40. https://doi.org/10.1016/j.compedu.2013.07.033 
Moreno, Y., Aguilar, J., \& Hidrobo, F. (2018). Análisis de los problemas de rendimiento en un EVA (entorno virtual de aprendizaje) a través de la extracción de conocimiento. Revista Ingeniería Al Día, 4(1), 3-24.

Navarro Delgado, I., \& Fonseca Escudero, D. (2017). Nuevas tecnologías de visualización para mejorar la representación de arquitectura en la educación. Architecture, City and Environment, 12(34), 219-238. https://doi.org/10.5821/ace.12.34.5290

Pantelidis, V. (1997). Virtual Reality as an instructional aid: A model for determining when to use VR. VR in the schools (Vol. 3).

Pantelidis, V. S., \& Vinciguerra, D. C. (2010). Virtual Reality in Education. In C. M. Stewart, C. C. Schifter, \& M. E. M. Selverian (Eds.), Teaching and Learning with Technology: Beyond Constructivism (pp. 151-181). New York: Routledge.

Passig, D., \& Sharbat, A. (2000). A preferred future pedagogic mission for using virtual reality (VR) in schools: An Imen-Delphi (ID) excercise with a group of VR scholars and developers. International Journal of Virtual Reality.

Pifarré, M., \& Tomico, O. (2007). Bipolar laddering (BLA): A participatory subjective exploration method on user experience. In Proceedings of the 2007 Conference on Designing for User eXperiences, DUX'07. https://doi.org/10.1145/1389908.1389911

Vera Ocete, G., Ortega Carrillo, J. A., \& Burgos González, M. Á. (2003). La realidad virtual y sus posibilidades didácticas. Etic@net, 2, 1-17. https://doi.org/10.1016/j.bcp.2018.07.015

Wickens, C. D. (1992). Virtual reality and education. In IEEE International Conference on Systemas, Man, and Cybernetics (pp. 842-847 vol.1). https://doi.org/https://doi.org/10.1109/ICSMC.1992.271688

Winn, W. (1993). A Conceptual Basis for Educational Applications. Technical Report TR93-9, Human Interface Technology Laboratory-University of Washington. 